Jurnal Pendidikan Dasar, 6 (2), Desember 2018

\title{
PENERAPAN MODEL COURSE REVIEW HORAY (CRH) UNTUK MENINGKATKAN KEAKTIFAN SISWA PADA MATA PELAJARAN IPA DI KELAS III SDN 7 KEBEBU
}

\author{
Ani Julia ${ }^{1}$, Rindah Permatasari ${ }^{2}$, Indria Susilawati ${ }^{3}$ \\ ${ }^{1}$ Mahasiswa STKIP Melawi Program Studi PGSD, \\ ${ }^{2,3}$ Dosen STKIP Melawi \\ Jl. RSUD Melawi km. 04 Kec. Nanga Pinoh Kab. Melawi Kalimantan Barat \\ anijulia694@gmail.com,rindahpermatasari@gmail.com, \\ smile_indria@yahoo.com
}

\begin{abstract}
The purpose of this study was to improve student learning activities in learning Natural Sciences through the Class III Course Review Horay (CRH) model at SDN 7 Kebebu. This type of research is Classroom Action Research (CAR) conducted in two cycles and two meetings. Data collection techniques are carried out using observation. The instrument of this research is the observation sheet of student learning activities and teacher activities. Data analysis techniques carried out by researchers by describing data quantitatively.Based on the research value of the number of 15 students who experienced an increase in learning activities by 61.27 with the category of less active in the first cycle and increased to 75.72 with the active category in cycle II. From these results it can be concluded that the Course Review Horay model that is applied in the learning process can increase student activity in science subjects in class III SDN 7 Kebebu.
\end{abstract}

Keywords: Student Learning Activities, Science Learning, Model Course Review Horay (CRH).

\begin{abstract}
Abstrak: Tujuan penelitian ini adalah untuk meningkatkan aktivitas belajar siswa pada pembelajaran Ilmu Pengetahuan Alam melalui model Course Review Horay (CRH) kelas III SDN 7 Kebebu. Jenis penelitian ini adalah Penelitian Tindakan Kelas (PTK) yang dilaksanakan dalam dua siklus dan dua kali pertemuan. Teknik pengumpulan data dilakukan dengan menggunakan observasi (pengamatan). Instrumen penelitian ini adalah lembar observasi aktivitas belajar siswa dan aktivitas guru. Teknik analisis data yang dilakukan oleh peneliti dengan mendeskripsikan data secara kuantitatif. Berdasarkan penelitian nilai dari jumlah 15 orang siswa yang mengalami peningkatan aktvitas belajar sebesar 61,27 dengan kategori kurang aktif pada siklus I dan meningkat menjadi 75,72 dengan kategori aktif pada siklus II. Dari hasil tersebut dapat disimpulkan bahwa model Course Review Horay yang diterapkan dalam proses pembelajaran dapat meningkatkan keaktifan siswa pada mata pelajaran IPA dikelas III SDN 7 Kebebu.

Kata Kunci: Aktivitas Belajar Siswa, Pembelajaran IPA,Model Course Review Horay $(\mathrm{CRH})$.
\end{abstract}

66| J P D, p - I S S N : 2252 - 8156 , e - I S S N : 2579 - 3993 
$\mathbf{B}_{\text {siswa yang dilakukan peneliti pada }}^{\text {erdasarkan observasi aktivitas }}$ tanggal 19 sampai 20 Juli 2018 di SDN

7 Kebebu diketahui bahwa aktivitas siswa di SD 7 Kebebu tergolong kurang aktif. Hal ini dapat dilihat dari lembar observasi pengamatan aktivitas siswa dimana rata-rata keaktifan siswa hanya 49,77 dan belum terlihat satu siswapun yang memiliki rata-rata aktivitas di atas 75. Dalam proses pembelajaran keaktifan belajar siswa masih kurang diakibatkan siswa kurang memahami materi ditunjukkan dengan aktivitas siswa ketika diberi pertanyaan siswa terlihat bingung untuk menjawab, kurang dalam mengemukakan pendapat dan tidak ada yang mengajukan pertanyaan saat guru memberikan kesempatan bertanya.

Berdasarkan observasi diketahui bahwa guru cenderung menggunakan model pembelajaran yang sama atau monoton. Pembelajaran terfokus pada guru sehingga siswa kurang aktif di kelas. Cara mengajar guru masih menggunakan metode ceramah, mencatat, tanya jawab. Ternyata metode ceramah dan tanya jawab yang dilakukan kurang mampu meningkatkan aktivitas siswa karena siswa cenderung merasa bosan, hal ini terlihat dari sikap siswa yang pasif dalam pembelajaran. Sikap pasif terlihat dari sikap siswa yang tidak peduli dalam mengikuti pembelajaran, ngantuk, sibuk berbicara dengan teman sebangku, bermain dikelas, sering izin keluar masuk kelas. Selain itu guru jarang memberikan kesempatan siswa untuk berfikir secara berkelompok dan mengakibatkan kemampuan berpikir kritis siswa dan kerja sama siswa menjadi kurang.

Berdasarkan masalah yang telah dibahas salah satu model pembelajaran yang dapat meningkatkan aktivitas, kerjasama, dan menyajikan banyak soal adalah model pembelajaran Course Review Horay (CRH). Pembelajaran Course Review Horay (CRH) adalah salah satu pembelajaran yang dapat mendorong siswa untuk ikut aktif dalam belajar. Pembelajaran Course Review Horay dicirikan oleh struktur tugas, tujuan, dan penghargaan kooperatif yang melahirkan sikap ketergantungan yang positif diantara sesama siswa, penerimaan terhadap perbedaan individu dan mengembangkan keterampilan bekerjasama antar kelompok. Penelitian relevan yang telah dilakukan menggunakan model Course Review Horay oleh Oleh Lika Pratiwi 
(2012/2013) yang dikatakan berhasil dalam meningkatkan aktivitas siswa.

Dalam penerapan model pembelajaran ini,Siswanto (2012:28) menjelaskan bahwa model pembelajaran Course Review Horay (CRH) merupakan model pembelajaran yang dapat menciptakan suasana kelas menjadi meriah dan menyenangkan karena siswa yang dapat menjawab benar maka siswa tersebut diwajibakan berteriak "hore" atau yel-yel lainnya yang disukai. Menurut Hamid Sholeh (2013:223) menyatakan bahwa pembelajaran Course Review Horay merupakan model yang menyenangkan, karena siswa diajak untuk bermain sambil belajar untuk menjawab berbagai pertanyaan yang disampaikan secara menarik dari guru.

Berdasarkan latar belakang yang telah diuraikan, peneliti mengidentifikasikan masalah antara lain: Kurangnya keaktifan belajar siswa dimana rata-rata keaktifan siswa hanya 49,77. Siswa kurang dalam mengemukakan pendapat.Siswa kurang mengajukan pertanyaan. Model pembelajaran yang monoton. Guru jarang memberikan kesempatan siswa untuk berfikir secara berkelompok. Dalam penelitian ini hanya membatasi masalah pada Kurangnya keaktifan belajar siswa terutama pada saat pemebelajaran IPA dan model pembelajaran yang monoton. Adapun masalahnya adalaha bagaimanakah Penerapan Model Course Review Horay (CRH) pada pembelajaran ipa dan apakah dengan penerapan Model Course Review Horay di Kelas III SDN 7 Kebebu aktivitas belajar siswa dapat meningkat?

Adapun langkah- langkah yang dapat diterapkan dalam pembelajaran melalui model Course Review Horay Langkah-langkah Model Pembelajaran Course Review Horay (CRH) menurut Huda 2013: 229 adalah sebagai berikut : "Guru meyampaikan kompetensi yang ingin dicapai, guru menyajikan atau mendemonstrasikan materi sesuai topik dengan tanya jawab, guru membagi siswa dalam kelompok- kelompok kecil 4-5 orang dalam satu kelompok, untuk menguji pemahaman, siswa diminta membuat kartuberisi kotak sesuai dengan kebutuhandan diisi dengan nomor yang ditentukanguru, guru membaca soal secara acak dan siswa menuliskanjawabannya di dalam kartu berisikan kotak yang nomornya disebutkan guru, setelah pembacaan soal dan jawaban siswa dituliskan didalam kartu berisikan kotak, guru dan siswa mendiskusikan soalyang telah diberikan 
tadi, bagi pertanyaan yang dijawab benar, siswa memberi tandacheklist $(\sqrt{ })$ dan lansung berteriak "hore!!" ataumenyanyikan yel-yelnya, Nilai siswa dihitung dari jawaban yang benar dan yangberteriak hore, guru memberikan reward pada kelompok yang memperolehnilai tertinggi atau yang paling sering memperoleh "hore!!".

Huda (2013 : 231) mengatakan tentang kelebihan dan kekurangan Model Pembelajaran Course Review Horay (CRH): kelebihan model pembelajaran ini antara lain: strukturnya yang menarik dan dapat mendorong siswauntuk dapat terjun kedalamnya, metode yang tidak monoton karena diselingi dengan hiburan sehingga suasana tidak menegangkan, semangat belajar yang meningkat karena suasana pembelajaran berlansung menyenangkan, skill kerja sama antarsiswa yang semakin terlatih. Kekurangan Model Pembelajaran ini antara lain :penyamarataan nilai antara siswa yang pasif dan aktif, adanya peluang untuk curang, beresiko menganggu suasana belajar kelas lain. Tujuan yang ingin dicapai dalampenelitian ini adalah untuk mengetahui bagaimana Dengan penerapan model Course ReviewHoray
(CRH) pada pembelajaran IPA di kelas III SDN 7 Kebebu untuk mengetahui peningkatan aktivitas belajar siswa setelah menggunakan model CRH.

\section{METODE PENELITIAN}

\section{Pelaksanaan Penelitian}

Pelaksanaan penelitian ini menggunakan rancangan Penelitian Tindakan Kelas (PTK). Penelitian tindakan kelas dari dua siklus dimana setiap siklus terdiri dari beberapa tahap,yaitu perencanaa, pelaksanaan, observasi, dan repleksi.Menurut Arikunto,(2006) "Penelitian Tindakan Kelas adalah penelitian yang dilakukan oleh guru dikelas atau sekolah tempat ia mengajar dengan menekankan pada penyempurnaan atau proses pembelajaran.

\section{Tempat dan Waktu Penelitian}

Tempat penelitian ini akan dilaksanakan di kelas III SDN 7 Kebebu yang terletak di Dusun Kebebu, Desa Kebebu, Kecamatan Nanga Pinoh, Kabupaten Melawi, Waktu penelitian dilakukan pada mata pelajaran Ilmu Pengetahuan Alam (IPA) berlangsung di semester ganjil tahun pelajaran 2018.

\section{Subjek dan Objek Penelitian}

Subjek penelitian ini adalah siswa kelas III SDN 7 Kebebu berjumlah 15 siswa yang terdiri dari 10 siswa perempuan dan 5 siswa laki-laki adapun 
sasaran yang ingin dicapai adalah aktivitas belajar siswa.

\section{Prosedur Penelitian}

Dalam melaksanakan penelitian tindakan kelas ini peneliti menggunakan penelitian tindakan model Kemmis dan Mc Taggar, Tampubolon, (2013:27). Model penelitian ini terdiri dari empat tahap, yaitu: a.Perencanaan (planning), b.Tindakan (acting), c.Pengamatan (observing) d.Refleksi (reflecting).

\section{Teknik Dan Instrumen Penelitian}

Teknik pengumpulan data di dalam penelitian ini adalah Teknik observasi yang dilakukan melalui pengamatan aktivitas melalui proses pengamatan terhadap kegiatan yang sedang berlangsung dilokasi penelitian.Instrumen dalam penelitian ini yang digunakan yaitu lembar observasi keterlaksanaan rencana pelaksanaan pembelajaran (RPP) dan lembar observasi aktivitas belajar siswa.

\section{HASIL DAN PEMBAHASAN}

\section{Siklus I}

Pelaksanaan tindakan kelas pada siklus I dilaksankan pada tanggal 28 Agustus dan 29 Agustus 2018. Penelitian ini dibantu oleh oleh dua orang observer, yaitu satu wali kelas III SDN 7 Kebebu dan satu teman sejawat sebagai observer serta dokumenter dan dihadiri siswa kelas III SDN 7 Kebebu.
Materi pembelajaran pada siklus I yaitu penggolongan Hewan. Berdasarkan data hasil observasi aktivitas belajar siswa dan aktivitas guru mengajar.

Hasil observasi aktivitas belajar siswa terhadap mata pelajaran Ilmu Pengetahuan Alam pada siklus I adalah 919,07 dengan nilai rata-rata 61,27 dengan 2 orang siswa yang dikategorikan cukup aktif , 13 orang siswa dikatergorikan kurang aktif dalam belajar.Dari hasil observasi, beberapa siswa sudah memperhatikan penjelasan peneliti tetapi sulit bekerjasama dalam diskusi, belum mengggunakan kesempatan bertanya dan menjawab serta mengemukakan pendapat secara maksimal. Data rata-rata hasil keterlaksanaan rencana pembelajaran yang dilakukan oleh peneliti disetiap pertemuan pada siklus I dengan rata-rata 84,53 sedangkan kriteria keberhasilan sudah ditentukan apabila telah mencapai $\geq 85 \%$ kualifikasi sangat baik. Rata-rata tersebut masih belum mencapai kriteria yang telah ditentukan, berdasarkan catatan observer pada pertemuan dalam proses belajar mengajar masih kurang dan perlu adanya perbaikan selanjutnya.

\section{SIKLUS II}

Pelaksanaan tindakan pada siklus II pertemuan dilaksanakan pada 3 september dan 4 september 2018. 
Penelitian ini dibantu oleh oleh dua orang observer, yaitu satu wali kelas III SDN 7 Kebebu dan satu teman sejawat sebagai observer serta dokumenter dan dihadiri siswa kelas III SDN 7 Kebebu. Materi yang akan disampaikan yaitu melanjutkan materi sebelumnya yaitu penggolongan tumbuhan. Dengan kegaiatan pembelajaran yang sama pada siklus I. Berdasarkan hasil refleksi pada siklus I. Berdasarkan data hasil observasi aktivitas belajar siswa dan aktivitas guru mengajar.

Berdasarkan data hasil observasi aktivitas belajar siswa dan aktivitas guru mengajar. Data mengenai aktivitas belajar siswa terhadap mata pelajaran Ilmu Pengetahuan Alam pada siklus II adalah 1.135,76 dengan nilai rata-rata 75,72 dengan 9 orang siswa yang dikategorikan aktif, 6 orang siswa dikatergorikan cukup aktif dalam belajar. Berdasarkan hasil tersebut peneliti dan observer merasa puas akan hasil yang diperoleh sudah mencapai kriteria keberhasilan yang diharapkan yaitu $\geq 75$ kualifikasi aktif.Data hasil observasi keterlaksanaan rencana pembelajaran peneliti dalam kegiatan mengajar pada siklus II dengan rata-rata 97,62. Rata-rata tersebut sudah mencapai kriteria yang telah ditentukan dan sudah dikatakan bahwa dengan menggunakan model Course Review Horay dapat meningkatkan aktivitas belajar siswa khususnya pada mata pelajaran IPA siswa kelas III Sekolah Dasar. Proses pembelajaran pada siklus II yang dianggap sudah mencapai kriteria yang diharapkan serta peneliti melakukan kegiatan pembelajaran dengan baik.

\section{Verifikasi}

Data hasil penelitian ini membuktikan hipotesis tindakan bahwa penerapan model Course Review Horay dapat meningkatkan aktivitas belajar IPA siswa kelas III SDN 7 Kebebu. Hal tersebut dapat dilihat dari setiap aspek aktivitas belajar siswa mengalami peningkatan. Selain itu, peningkatan aktivitas belajar siswa juga didukung dari rata-rata seluruh indikator aktivitas belajar siswa yang diamati pada lembar observasi sebesar 61,27 pada siklus I menjadi 75,72 pada siklus II dengan peningkatan sebesar 14,92. Jadi dapat disimpulkan aktivitas belajar siswa meningkat dari siklus I ke siklus II.

Data peningkatan hasil keterlaksanaan proses KBM yang dilakukan peneliti pada siklus I dan siklus II yang mengalami peningkatan. Pada siklus I kegiatan awal sebesar 78,6 sedangkan pada siklus II menjadi 92,86 peningkatan siklus I ke siklus IIsebesar 71| J P D, p-IS S N : $2252-8156$, e - I S S N : $2579-3993$ 
14,26.Kegiatan inti siklus I sebesar 100 sedangkan pada siklus II menjadi 100 peningkatan siklus I ke siklus IIsebesar 0 dan kegiatan penutup siklus I sebesar 75 sedangkan pada siklus II menjadi 100 peningkatan siklus I ke siklus IIsebesar 25.Rata-rata siklus I sebesar 84,53, siklus II sebesar 97,62 dengan penigkatan sebesar 13,09.Pada penelitian ini peneliti menemukan beberapa temuan yang pertama siswa dengan inisial MAAS memiliki nilai rata-rata terendah yaitu 57,14 disiklus I dan 69,05 disiklus II dikarenakan dalam aspek keaktifan khususnya pada indikator mengajukan pertanyaan dan mengemukakan pendapat kurang aktif atau tidak memenuhi indikator yang ingin dicapai oleh peneliti.

Hal tersebut terjadi karena dalam proses pembelajaran siswa tersebut kurang percaya diri, ketika belajar hanya diam memperhatikan guru saja, serta siswa dengan inisial MAAS memang belum mengenal huruf sehingga menyebabkan inisial MAAS belum bisa membaca.Pada temuan peneliti yang kedua siswa dengan inisial BAP mempunyai peningkatan paling tinggi yaitu 19,05 dari 61,9 menjadi 80,96. Peningkatan tersebut terjadi karena rasa percaya diri untuk melakukan aktivitas belajar yang terdapat dalam indikator aspek penilaian, terutama siswa sudah mampu mengemukakan pendapatnya dengan baik, mengajukan pertanyaan dan berdiskusi kelompok. Kemudian siswa dengan inisial VV dengan peningkatan paling rendah yaitu 9,53 dari 61,91 menjadi 71,44. Siswa tersebut mengalami peningkatan yang paling rendah dikarenakan VV kurang dalam aspek bertanya dan mengemukakan pendapat. Dari hasil perhitungan tersebut membuktikan bahwa dalam belajar peran aktif siswa mengalami peningkatan.

\section{SIMPULAN}

Berdasarkan data hasil Penelitian Tindakan Kelas (PTK) dapat disimpulkan bahwa penerapan model Course Review Horay(CRH) dapat meningkatkan keaktifan belajar siswa pada mata pelajaran IPA kelas III SDN 7 Kebebu.Dari hasil observasi terhadap aktivitas siswa selama pembelajaran, dapat diketahui bahwa aktivitas siswa mengalami peningkatan disetiap siklus. Aktivitas belajar siswa juga didukung dari rata-rata seluruh indikator aktivitas belajar siswa diperoleh nilai rata-rata sebesar 61,27 pada siklus I menjadi 75,72 pada siklus II dengan peningkatan sebesar 14,45. Hal ini menunjukan bahwa model Course Review Horay 
Jurnal Pendidikan Dasar, 6 (2), Desember 2018

dapat meningkatkan aktivitas siswa dalam pembelajaran.

\section{DAFTAR PUSTAKA}

Arikunto, S. 2006. Penelitian Tindakan Kelas. Jakarta: Bumi Aksara

Huda, M. 2013. Model-Model Pengajaran Dan Pembelajaran. Isu-Isu Metodis Dan Pragmatis. Yogyakarta: Pustaka Pelajar.

Hamid, S. 2013. Metode Edu Taiment. Jogjakarta: Diva Press.

\begin{abstract}
Siswanto, B. 2012. Belajar Dengan Pendekatan PAIKEM. Jakarta: PT Bumi Aksara
\end{abstract}

Tampubolon, S. 2013. Penelitian Tindakan Kelas: Sebagai Pengembangan Propesi Pendidik dan Keilmuan. Jaarta: Penerbit Erlangga

73| J P D, p-IS S N : 2252 - 8156 , e - I S S N : $2579-3993$ 